\title{
Subacute Toxicity of Butanol Fraction of Tali Putri Plants (Cassytha filiformis L.) Against Hematology Parameters of White Male Mice
}

\author{
Dwisari Dillasamola ${ }^{1}$, Annisa Yatursyi ${ }^{1}$, Armenia $^{1, *}$
}

\section{Dwisari Dillasamola ${ }^{1}$, Annisa Yatursyi ${ }^{1}$, Armenia ${ }^{1, *}$}

'Unit of Pharmacology and Clinical Pharmacy, Faculty of Pharmacy, Andalas University, Padang, INDONESIA.

\section{Correspondence}

Armenia Armenia

Unit of Pharmacology and Clinical

Pharmacy, Faculty of Pharmacy, Andalas

University, Padang, INDONESIA.

E-mail: armenia@phar.unand.ac.id

History

- Submission Date: 03-09-2019;

- Review completed: 09-10-2019;

- Accepted Date: 11-10-2019.

DOI : 10.5530/pj.2020.12.5

Article Available online

http://www.phcogj.com/v12/i1

Copyright

(C) 2020 Phcogj.Com. This is an openaccess article distributed under the terms of the Creative Commons Attribution 4.0 International license.

\begin{abstract}
Hematotoxicity study of butanol fraction of Cassytha filiformis L. on white male mice has been performed. A total of 12 white male mice were used, and they were divided into four groups. Each group consists of 3 mice. These animals were treated with Cassytha filiformis $\mathrm{L}$. butanolic fraction at several doses of $2.5,5$, and $10 \mathrm{mg} / \mathrm{kg}$ for seven days. Hemoglobin value, erythrocytes, platelets, leukocytes, monocytes, lymphocytes, eosinophils, neutrophils, and basophils counts were measured at the $1^{\text {st }}, 3^{\text {rd }}$, and $7^{\text {th }}$ day of treatment. The data of this study were analyzed using two-way ANOVA, followed by Duncan's multiple region tests. The results showed that the doses of butanol fraction did not affect hemoglobin value, erythrocytes, leukocytes, and neutrophils $(p>0.1)$, but it significantly reduced platelet, monocyte, lymphocyte count, and increases eosinophils $(p<0.01)$ counts within their normal limits. There is no influence on the duration of administration and the interaction of dosage, and also the duration of use of the parameters above. This result implies that the Cassytha filiformis butanol fraction at doses of $2.5-10 \mathrm{mg} / \mathrm{kg}$ does not affect hematology parameters if it were used for seven days.
\end{abstract}

Key words: Cassytha filiformis L.; Butanol fraction; Subacute toxicity; Haematology.

\section{INTRODUCTION}

Throughout their history, natural products from plants have played a significant role in sustaining human life, especially for food sources and medicinal products. ${ }^{1}$ Many drugs that have been used now were already known long before science developed, especially for stimulants or drugs that reduce pain. The community's knowledge of the use of traditional medicine is still based on a downward experience. People assume that the use of medicinal plants regularly will not cause harm because it comes from plants. The statement is very unjustified because the use of medicinal plants that are not at the right the dose could be harmful. Medicinal plants can be said to be safe if it used in the right dosage. ${ }^{2}$

One of the plants which is believed to possess pharmacological effects is the Tali Putri plant, which is one of the parasitic plants. Cassytha filiformis L., commonly known as 'Wu-kentaso', is a twisted parasite herb that widely distributed along the southern coast of Taiwan. It is reported to be useful as a medication for gonorrhea, kidney disease, and also as a diuretic. ${ }^{3}$

Several groups of bioactive compounds such as alkaloids, phenols, carbohydrates, saponins, flavonoids, terpenoids, and tannins have been successfully identified from Cassytha filiformis. ${ }^{4}$ Several new chemical compounds with interesting pharmacological properties have been found in this plant. These compounds mainly affect the cardiovascular system. Various activities, such as antiparasitic and cytotoxic effects have also been reported. ${ }^{5}$

Blood is the primary transporter in the body (transportation, distribution, and circulation), and the total amount of blood in humans, human wtih the body wight of $70 \mathrm{~kg}$ is 5 liters. The function of blood in general is: transporting foods' nutrients from the intestine to body tissues; maintaining the osmotic pressure between blood and cell tissues to remain normal; keeping the balance of acid-base in the blood balanced; regulating body temperature; and as a defense against diseases.?

Above all, action needed to evaluate the safety of butanol fraction of Cassytha filiformis L. on mice blood circulation before further study on the clinical field.

\section{METHODS}

The test animals used were twelve male white mice with an average weight of 20-30 grams and at the age of 12 months. The dosage given to white male mice was $2.5,5$, and $10 \mathrm{mg} / \mathrm{kg}$. The test preparation was given orally. The selection of these doses was based on the effect of Tali Putri therapy as an anticoagulant. ${ }^{8}$

\section{RESULT}

Hematological features of mice can be seen in Figure 1. Based on statistical tests that were carried out, the results showed that the dosage and duration of treatment, and also the interaction between the doses of Tali Putri plant's butanol fraction did not affect the hemoglobin value, the number of erythrocytes, 
neutrophil, and mean leukocyte counts $(p>0.1)$. Statistically, the dose and duration of treatment, and also the interaction between the doses of Tali Putri plant's butanol fraction did affect the platelet, monocyte, lymphocyte, and eosinophil counts in the average group of test animals significantly $(p<0.01)$ (Figures 2-9).

\section{DISCUSSION/ CONCLUSION}

This research was a follow-up study which aims to determine the toxic effects of the butanol fraction of Tali Putri against hematology of male white mice. The use of this sample was based on the results of previous studies that had proven the anticoagulant effect of the water, butanol, and ethyl acetate fractions of Cassyth a filiformis L. ${ }^{8}$ The results of the subacute toxicity test of the butanol fraction against hematology were expected to provide information about the level of safety of a substance against test animals and to become an additional data related to the safety of the use of Tali Putri plants and its development into phytopharmaceutical drugs (Table 1).

The sample used in this study was the butanol fraction of Tali Putri plants (Cassytha Filiformis L.) which was taken from the fat-free ethanol extract that obtained from the result of previous studies by Ananda (2016) and Fitria (2016), ${ }^{8,9}$ Fractionation is a process of separating compounds based on polarity, that is from polar, semi-polar and polar compounds. Each of these polarity levels has different toxicity when compared with the form of the extract itself.

Some researchers have previously conducted research related to the toxicity of Tali Putri plants. Toxicity tests using mice for the test animals as a model were used to see the presence of biochemical, physiological, and pathological reactions in humans to the samples that were used. ${ }^{10}$ The result of the toxicity test can be used as a guide to the presence of relative toxicity and as a help to identify the toxic effects in humans, but toxicity tests cannot be used as an absolute result of the safety of a substance.

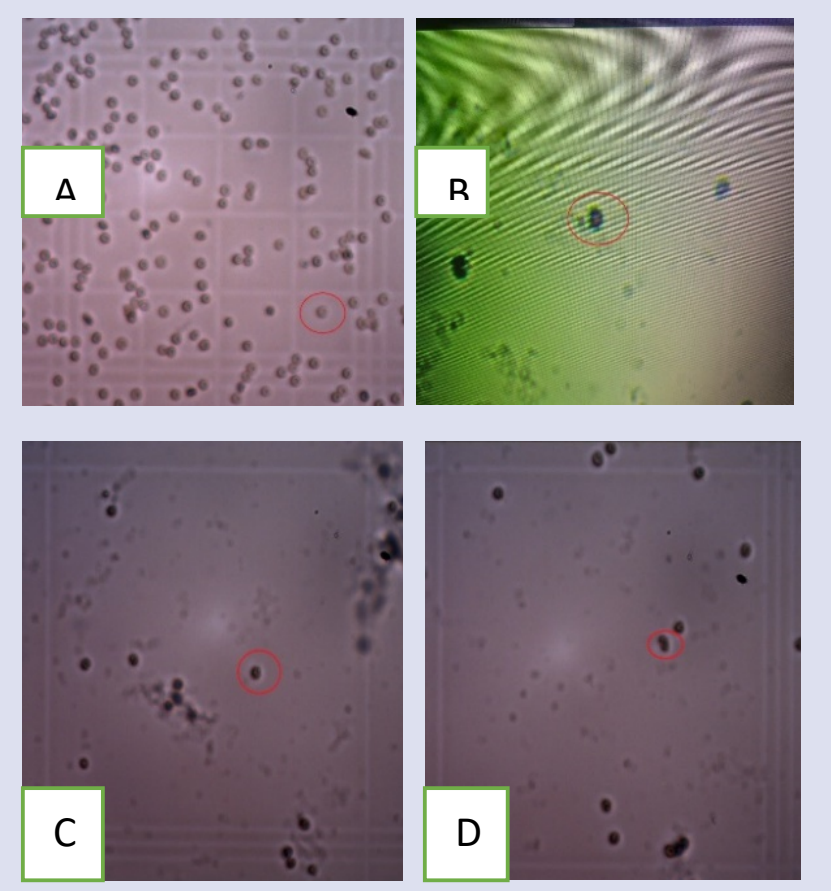

Figure 1: Hematological features of mice; (A) Erythrocyte cells, (B) Eosinophil cells, (C) Neutrophil cells, (D) Monocyte cells with a Primo Star Zeiss microscope in 10x magnification.

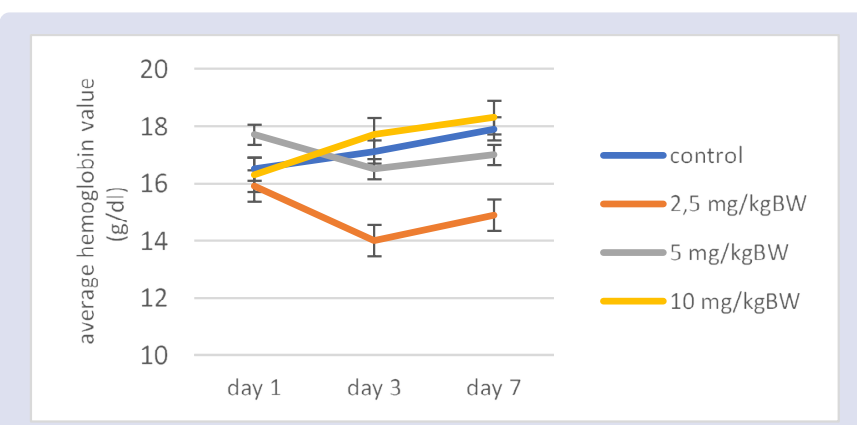

Figure 2: Effect of dose and length of observation on changes in value hemoglobin.

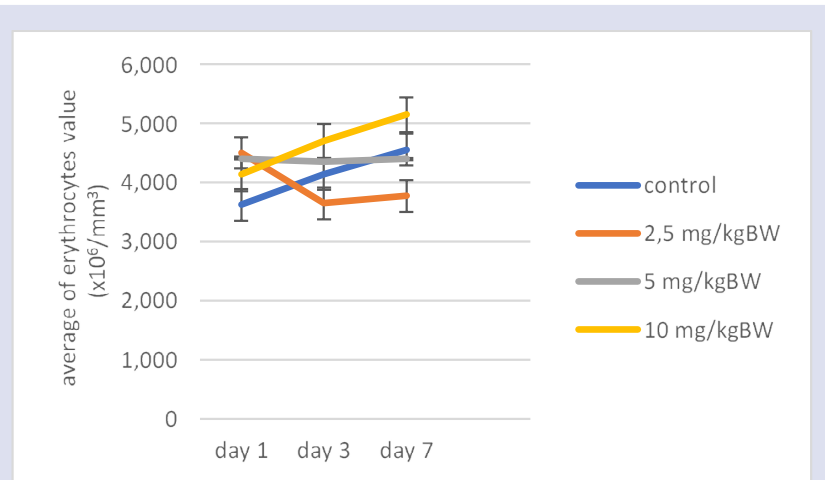

Figure 3: Effect of dose and length of observation on the number of erythrocytes.

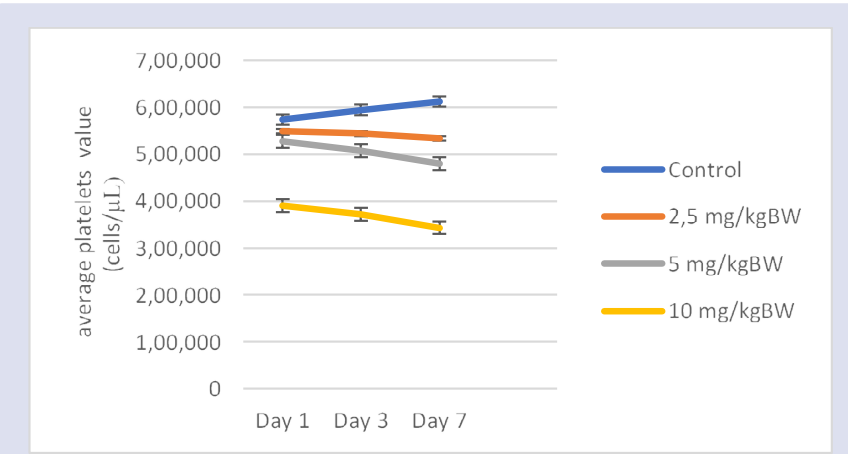

Figure 4: Effect of dose and length of observation on platelet counts.

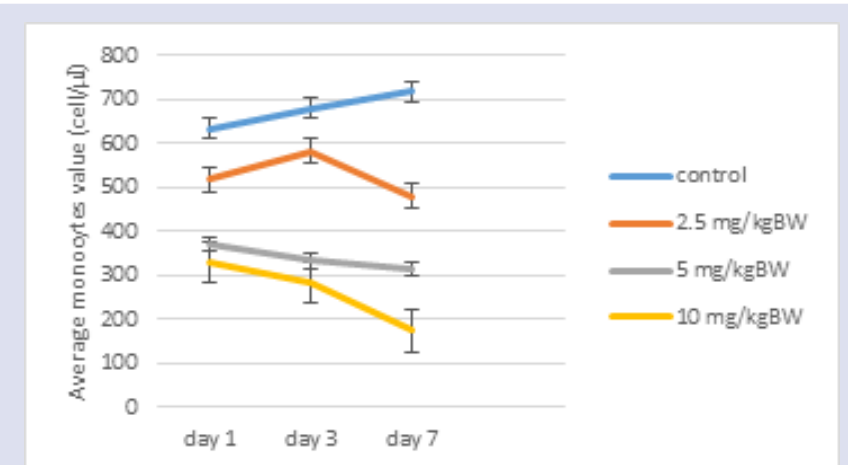

Figure 5: Effect of dose and length of observation on monocyte counts. 


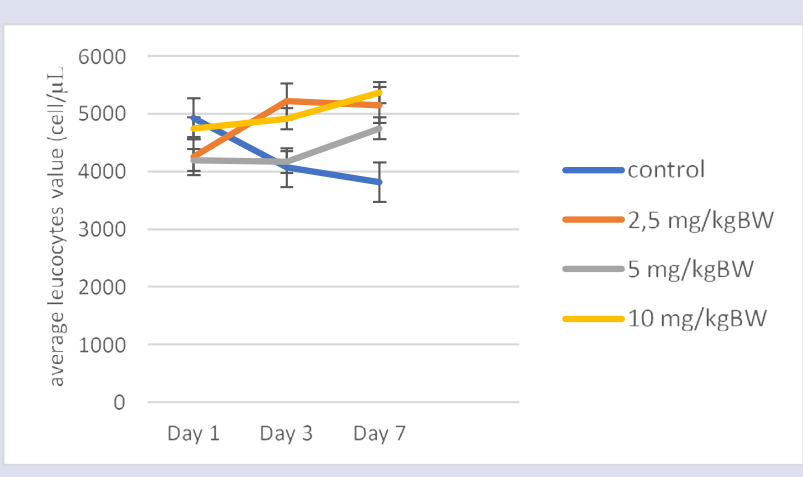

Figure 6: Effect of dose and length of observation on leukocyte counts.

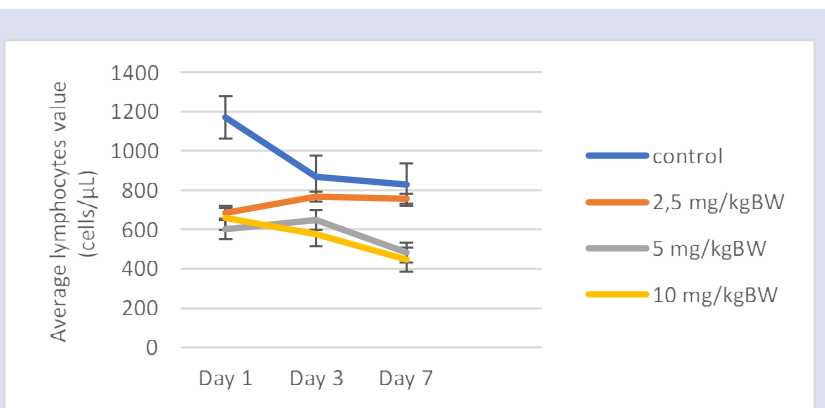

Figure 7: Effect of dose and length of observation on lymphocyte counts.

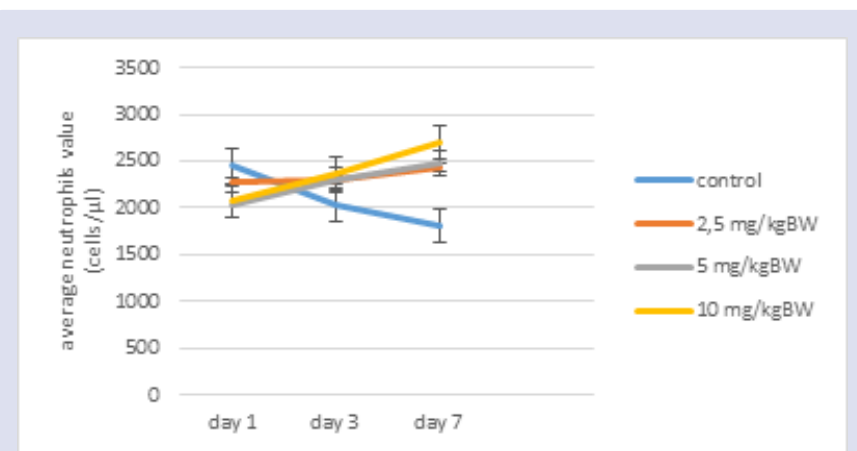

Figure 8: Effect of dose and length of observation on the number of neutrophils.

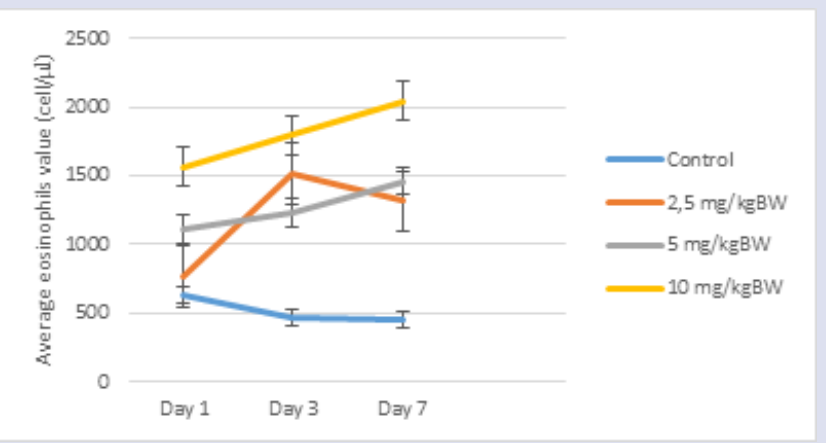

Figure 9: Effect of dosage and duration of observation on eosinophil counts.
Toxicity tests are divided into 2 categories: (1) local toxicity that occurs in the first place of contact between biological systems and toxicity, and (2) systemic toxicity that occurs in the circulatory system, hematopoietic system and blood, visceral organs such as the liver, kidneys and lungs. ${ }^{10}$ The toxicity test that carried out in this study was the subacute toxicity test in blood. The examination was carried out on several components of blood, such as hemoglobin value, erythrocyte count, platelet count, and leukocyte count (monocytes, lymphocytes, neutrophils, eosinophils, and basophils).

Repeated dosing of butanol fractions that were generally given for one week is known as subacute testing. ${ }^{11}$ This study uses the doses that have been used in the previous studies from Tali Putri plants, which are in doses of $2.5 \mathrm{mg} / \mathrm{kg}, 5 \mathrm{mg} / \mathrm{kg}$, and $10 \mathrm{mg} / \mathrm{kg}$ that given orally to the test animal group to get the effect of blood pressure decrease, blood sugar reduction, and anticoagulants. ${ }^{5,12}$

Wistar strain of male white mice at the age of 2-3 months old and weighed 20-30 grams were used as the test animals for this study. Mice are meet the requirements to be a model of the test animals, and they also have similar pharmacokinetic and pharmacological principles when compared to humans. ${ }^{11}$ Because of the anticoagulant effects that have been reported before, research on butanol fraction was continued against other blood components, including hemoglobin value, erythrocyte count, platelet count, and leukocyte count (monocytes, lymphocytes, neutrophils, eosinophils, and basophils).

In previous studies, it was already known that Cassytha filiformis $\mathrm{L}$. had cytotoxic components. ${ }^{4}$ Cytotoxic components are compounds that can be toxic or used as drugs to inhibit the growth of cancer and tumor cells. ${ }^{13}$ Anti-tumour or anti-cancer (chemotherapy) is a cytostatic compound which provides unexpected side effects, such as (1) infection, occurs due to decreased white blood cells; (2) anemia, due to reduced red blood cells; and (3) bruising or bleeding, due to a decrease in blood platelets (Pancreatic Cancer).

In this study, the butanol fraction of Tali Putri plant increases the number of leukocytes and eosinophils in the blood. Based on the data analysis results, this fraction increases the number of eosinophils. This might be due to the saponin compounds that consisted of the Tali Putri plant. Saponin is one of the bioactive compounds that can found in these plants. ${ }^{14-15}$ According to Francis et al. (2002), the effect of saponins can result in irritation of the digestive tract and respiratory tract mucous. ${ }^{16}$ This infection stimulates the formation of eosinophils. Also, saponins can stimulate the immune system and increase antibody production. ${ }^{17}$ Saponins also have immunostimulatory activity, and that is at this point there is an increment of the number of leukocytes in the test animals group with butanol fractions given. ${ }^{18}$ There is no evidence that an immunostimulatory effect exists in Tali Putri plants before, so further testing needs to be done. Unfortunately, in this study, the presence of basophil cells cannot be detected by available methods. This might occur because of the small number of basophil cells exist in the blood. ${ }^{19}$ However, all the measurement parameters in this study were still in the normal range.

Based on the research that has been done, it can be concluded that the butanol fraction of Tali Putri plant (Cassytha filiformis L.) can reduce blood cells number excepts for eosinophils and leukocytes, which were increased, but still within the normal limits. The butanol fraction of Tali Putri plant (Cassytha filiformis L.) was not toxic to blood at the dose used in this study. Further studies regarding the impact of the butanol fraction of Tali Putri plant (Cassytha filiformis L.) administration against the immunostimulant system need to be explored. 
Table 1: Effect of Cassytha filiformis L. fraction of butanol on blood grains.

\begin{tabular}{|c|c|c|c|c|c|c|c|c|}
\hline $\begin{array}{c}\text { Dosis } \\
\mathrm{Mg} / \mathrm{kgBB}\end{array}$ & Hemoglobin & Erythrocytes & Platelet & Leucocytes & Monocytes & Lymphocytes & Eosinophils & Neutrophils \\
\hline 0 & $17,19 \pm 0,71 \mathrm{~b}$ & $17,19 \pm 0,71 b$ & $593,8 \pm 8,69 \mathrm{~d}$ & $4,27 \pm 0,23$ & $0,68 \pm 0,04 c$ & $0,96 \pm 0,06 \mathrm{~b}$ & $0,52 \pm 0,06 \mathrm{a}$ & $2,10 \pm 0,12$ \\
\hline 2,5 & $14,94 \pm 0,71 \mathrm{a}$ & $14,94 \pm 0,71 \mathrm{a}$ & $542,2 \pm 8,69 c$ & $4,87 \pm 0,23$ & $0,53 \pm 0,04 b$ & $0,74 \pm 0,06 \mathrm{a}$ & $1,19 \pm 0,06 \mathrm{~b}$ & $2,39 \pm 0,12$ \\
\hline 5 & $17,10 \pm 0,71 b$ & $17,10 \pm 0,71 b$ & $504,9 \pm 8,69 b$ & $4,37 \pm 0,23$ & $0,34 \pm 0,04 \mathrm{a}$ & $0,57 \pm 0,06 \mathrm{a}$ & $1,27 \pm 0,06 \mathrm{~b}$ & $2,28 \pm 0,12$ \\
\hline 10 & $17,45 \pm 0,71 \mathrm{~b}$ & $17,45 \pm 0,71 b$ & $368,4 \pm 8,69 a$ & $5,01 \pm 0,23$ & $0,26 \pm 0,04 \mathrm{a}$ & $0,57 \pm 0,06 \mathrm{a}$ & $1,80 \pm 0,06 \mathrm{c}$ & $2,38 \pm 0,12$ \\
\hline
\end{tabular}

\section{ACKNOWLEDGMENT}

The authors would like to deliver a special appreciation to the Dean of Pharmacy of Faculty Universitas Andalas for the financial Research Grant of Universitas Andalas

\section{CONFLICTS OF INTEREST}

There is no conflicts of interest in this study.

\section{REFERENCES}

1. Cseke LJ, Kirakosyan A, Kaufman PB, Warber S, Duke JA, Brielmann HL. Natural Products from Plants 2nd edition. United States of America: Taylor \& Francis Group, LLC; 2006.

2. Sukmono RJ. Overcoming Various Diseases with Herbal Therapy. Jakarta: Agromedia Reader; 2009.

3. Wu Y, Chao Y, Chang F, Chen Y. Alkaloids from Cassytha filiformis L. Phytochemistry. 1997;46(1):181-4

4. Mythili S, Gajalakshmi S, Sathiavelu A, Sridharan TB. Pharmacological activities of Cassytha filiformis: A review. Asian Journal of Plant Science and Research. 2011;1(1):77-83.

5. Yuliandra $Y$, Armenia A, Arifin $H$. Antihypertensive and antioxidant activity of Cassytha filiformis L: A correlative study. Asian Pacific Journal of Tropical Biomedicine. 2017;7(7):614-8.

6. American Society of Hematology. Blood disorders. [cited 2018 Aug 10] Available from: http://www.hematology.org/Patients/Blood-Disorders.aspx

7. D'Hiru. Live Blood Analysis. Jakarta: PT Gramedia Pustaka Utama; 2013.
8. Fitria. Test the anticoagulant effect of several fractions of princess string plant extracts (Cassytha filiformis L.) in diabetes-induced white male mice alloxan. Thesis, Andalas University, Padang, Indonesia, 2016.

9. Ananda R. Test the antidiabetic effect of several daughter plant fractions on male white mice induced with alloxan. Thesis, University Andalas, Padang, Indonesia, 2016.

10. Mayangsari E, Bayu L, Setyawati S, Nurdiana N, Permatasari N, Kalsum U, et al. Basic Pharmacology. Malang: Brawijaya Press University; 2017.

11. Lu FC, Kacew S. Lu's Basic Toxicology Fundamentals, Target Organs, and Risk Assessment (5th edition). New York: CRC Press; 2010.

12. Armenia N, Alen $Y$, Ismed F, Yuliandra $Y$, Ananda R, Fitria F. Blood sugar lowering effectiveness of Cassytha filiformis fractions on diabetic mice. Research Journal of Pharmaceutical, Biological and Chemical Sciences. 2016;7(6):1142-7.

13. Ervizal AMZ, Cancer Disappears Thanks to Soursop. Jakarta: AgroMedia; 2011.

14. Mythili S, Sathiavelu A. High performance thin layer chromatography profile of Cassytha filiformis. Asian Pacific Journal of Tropical Biomedicine. 2012:S1431-5.

15. Adonu CC, Esimone CO, Attama AA, Ugwueze MC. In vitro evaluation of antibacterial activity of extracts from Cassytha filiformis linn against urogenital clinical gram-negative bacteria: International Journal of Pharmacy and Biological Sciences. 2013;3(2):99-107.

16. Francis G, Kerem Z, Makkar HPS and Becker K. The Biological Action of Saponins in Animal systems: A review. British Journal of Nutrition. 2002;(88):587-605.

17. Oda K, Matsuda H, Murakami T, Katayama S, Ohgitani T, Yoshikawa. Adjuvant and haemolytic activities of 47 saponins derived from medicinal and food plants. Biological Chemistry. 2000;381:67-74.

18. Barr IG, Sjolander A, Cox JC. ISCOMs and other saponin based adjuvants (Review). Advanced Drug Delivery Reviews. 1998;(32):247-71.

19. Kiswari R. Hematology \& Transfusion. Jakarta: Erlangga; 2014.

Cite this article: Dillasamola D, Yatursyi A, Armenia. Subacute Toxicity of Butanol Fraction of Tali Putri Plants (Cassytha filiformis L.) Against Hematology Parameters of White Male Mice. Pharmacog J. 2020;12(1):25-8. 